\title{
Obituaries
}

Obituaries should be submitted by email to Jadene Doak at jadene.doak@springernature.com

All submitted obituaries should be 400 words maximum in length (apart from obituaries for past presidents of the BDA where the length should be 800 words).

Content of the obituary is down to the individual author, and the approval of the family should be given for the obituary prior to submission to the BDJ.

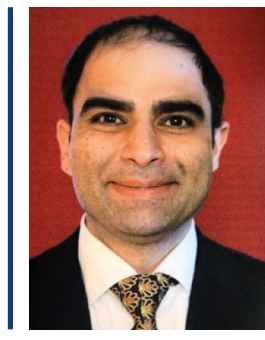

Morad Milanifar

$1973-2021$

Morad Milanifar was born in Tehran, Iran in 1973, and qualified as a dentist from Guy's and St Thomas' Hospital, London in 1997. He worked as an associate dentist for a few years, gaining further credentials with international courses before setting up his own multisurgery practice in Central London.

His unrelenting fervour and unbreakable passion for dentistry meant Morad was always seeking the newest technologies and techniques to provide his patients with the highest standard of care. His enthusiasm for staying at the forefront of his field took him far and wide to learn as much as he could, and he was always keen to impart his wisdom, tips and tricks to us all.

We both made our first ever forays into dentistry as teenagers with a fortnight each of work experience at Morad's practice. Seeing his boundless energy, unbridled creativity and zeal for dentistry inspired us and countless others to follow suit. His energy was electric and his enthusiasm infective. He was generous with his time and his knowledge, and his colleagues and patients will never forget this.

Morad had an insatiable curiosity for how things worked, always asking 'why?' with his cheeky grin and a Coca Cola to hand. He would take machines apart and put them back together to better understand them. He loved documentaries about the human body and about nature. He painstakingly cultivated over many years a hugely impressive garden of tomatoes, peppers and herbs which were enjoyed by all.

He was a wonderful son, grandson, brother, uncle, cousin, nephew, friend and dentist. His love for dentistry enthused many future generations of clinicians. He will be remembered by us all as an inspirational, inquisitive, generous, strong-hearted man and he is dearly missed.

Ariane Sampson and Victoria Sampson

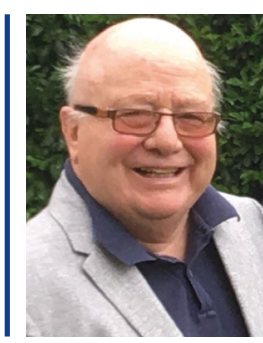

\section{Michael Lennon OBE}

$1943-2021$

Professor Michael Lennon OBE died aged 78 on 9 April. He qualified from Liverpool Dental School in 1966 and shortly afterwards gained the Diploma in Public Dentistry from Dundee University. He was appointed by the University of Manchester as a Lecturer in Periodontology and Dental Public Health, becoming Senior Lecturer in Community Dentistry in 1980. Together with Professor Phil Holloway he developed undergraduate training outside the dental school. This 'outreach' approach has now been adopted by every dental school in the country. They were co-directors of the trial of capitation for the Department of Health. With enthusiasm for evidence-based dentistry, the aspect of education that he most enjoyed was postgraduate supervision. He had a challenging but supportive approach, which brought out the best in his students.

In 1985, he became the first Regional Dental Officer (part-time) for the NorthWestern Regional Health Authority, becoming a committed advocate for water fluoridation. He was Chairman of the
British Fluoridation Society, a position he held from 1987-2012.

In 1989, Mike was appointed by the University of Liverpool to a Chair in Periodontology and Preventive Dentistry, subsequently re-titled Dental Public Health. On retirement he was appointed Emeritus Professor.

In 2003, he moved to the University of Sheffield to a Chair in Dental Public Health role, to establish and manage Sheffield's outreach programme, retiring in 2009. His immense commitment to Dental Public Health continued until prevented by ill-health. He published over 100 articles in refereed journals on topics including fluoridation, fluoridated milk, periodontal epidemiology, development of new practices, and capitation. His concern about social injustice and health inequalities influenced much of his research.

In 2010, he became Editor of Community Dental Health, the journal of the British Association for the Study of Community Dentistry, hugely time-consuming work which he performed with distinction until 2016. A founder member of BASCD, he served the Association as secretary, 1977-1981, and President 1984-1985. His contribution to oral health was recognised with the award of the OBE in the Queen's 80th Birthday Honours List.

Away from work his interests included classical music, and Everton FC. His busy professional life would not have been possible without the support of his wife Gill, whom he met at Liverpool Dental School. They celebrated their Golden Wedding Anniversary in December 2019.

We extend condolences to Gill, their four children and nine grandchildren on the loss of a remarkable, lovable, and irreplaceable man.

Geoff Taylor 